Pobrane z czasopisma Annales I - Philosophy and Sociology http://philosophia.annales.umcs.pl Data: 26/04/2023 16:32:06

DOI: $10.17951 /$ i.2016.41.2.103

A N N A LES

UNIVERSITATIS MARIAE CURIE-SKŁODOWSKA

LUBLIN - POLONIA

VOL. XLI, 2

SECTIO I

2016

\title{
Aktywność zawodowa w opinii pracujących kobiet
}

Professional Activity in the Opinion of Working Women

\section{WPROWADZENIE}

W ostatnich kilkudziesięciu latach obserwuje się wzrost aktywności zawodowej kobiet. Przyczyn należy upatrywać m.in. w procesach industrializacji i rozwoju gospodarki (a zwłaszcza sektora usług i popytu na pracę kobiet), we wzroście poziomu wykształcenia kobiet oraz w zmianach systemu wartości, które z kolei pociągają za sobą przemiany w rolach wypełnianych przez kobiety i mężczyzn. Oczywiście kobiety nadal spełniają się jako żony i matki, ale praca zawodowa stanowi dla nich także istotną wartość. Najczęściej realizowanym modelem ekonomicznym w polskich rodzinach jest model z obojgiem pracujących rodziców. Aktywność zawodowa kobiet jest zatem z jednej strony efektem wskazanych wyżej procesów, $\mathrm{z}$ drugiej zaś generuje zmiany w funkcjonowaniu rynku pracy i rodziny.

Celem artykułu jest przedstawienie opinii kobiet na temat ich aktywności zawodowej. Dlaczego kobiety pracują zawodowo? Czy tylko czynniki ekonomiczne mają znaczenie? Jakie korzyści kobiety czerpią z podejmowania aktywności zawodowej? Czy widzą siebie na stanowisku kierowniczym? Wreszcie, jaką mają opinię na temat dyskryminacji kobiet w sferze zawodowej i czy same spotkały się z jej przejawami? Próba odpowiedzi na te pytania zostanie podjęta w oparciu o wyniki badań przeprowadzonych wśród pracujących kobiet Lublina ${ }^{1}$. W części pierwszej artykułu zostanie przedstawiona aktywność zawodowa kobiet w Polsce

1 W artykule wykorzystano wyniki badań przeprowadzonych w 2016 r. w ramach seminarium 
Pobrane z czasopisma Annales I - Philosophy and Sociology http://philosophia.annales.umcs.pl Data: 26/04/2023 16:32:06

na podstawie danych GUS-u. W części drugiej będzie omówiona opinia kobiet o pracy zawodowej, zaś w trzeciej - kwestia dyskryminacji kobiet w sferze zawodowej.

\section{AKTYWNOŚĆ ZAWODOWA KOBIET W POLSCE²}

Zwiększanie aktywności zawodowej kobiet następowało stopniowo, ale regularnie. Jak wskazują dane GUS-u, udział kobiet w liczbie zatrudnionych w Polsce w $1950 \mathrm{r}$. wynosił około $31 \%$, w połowie lat $70 .-40 \%$, na początku lat $90 .-45 \%$, zaś w 2014 r. - blisko 49\%. Rośnie zatem współczynnik aktywności zawodowej kobiet. W 2015 r. osiągnął on poziom 48,6\% (dla mężczyzn - 65\%). Oznacza to jednocześnie, iż poziom aktywności zawodowej kobiet jest niższy niż mężczyzn, ponieważ wśród ogółu ludności biernej zawodowo 61,6\% stanowią właśnie kobiety. Najczęściej aktywność zawodowa kobiet plasuje się w przedziale wieku 25-50 lat. Najwyższy odsetek aktywnych kobiet przypada na przedział 40-49 lat (rys. 1). Najbardziej aktywne zawodowo są kobiety z wyższym poziomem wykształcenia (współczynnik wynosi blisko $80 \%$, dla pozostałych poziomów wykształcenia odpowiednio: policealne - blisko $60 \%$, średnie ogólnokształcące - około $40 \%$, zasadnicze zawodowe - blisko 50\%).

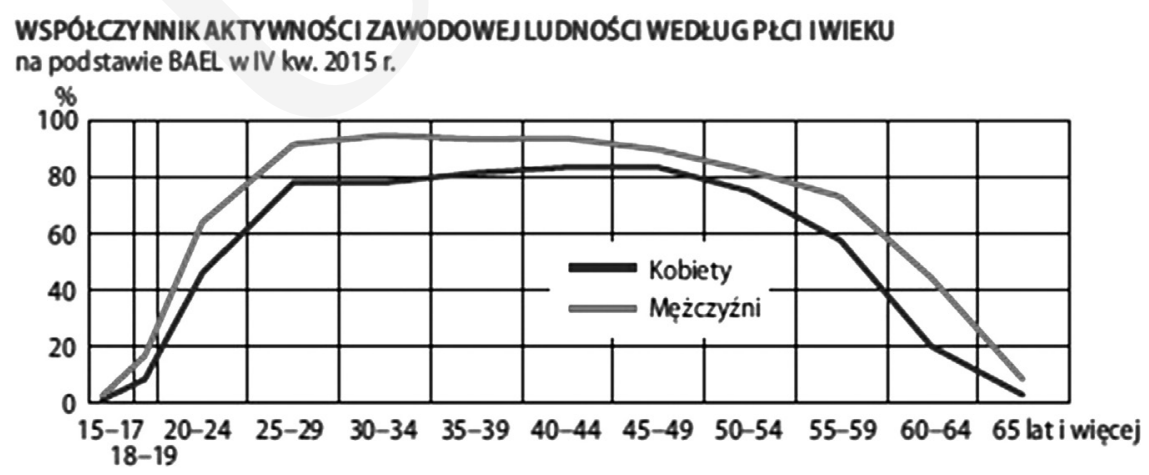

Rys. 1. Współczynnik aktywności zawodowej ludności według wieku i płci Źródło: GUS, Kobiety i mężczyźni na rynku pracy, Warszawa 2016, s. 4.

Wzrasta także wskaźnik zatrudnienia kobiet. W 2015 r. wyniósł ogółem 45,2\% (dla mężczyzn - 60,6\%), zaś wśród kobiet w wieku produkcyjnym - 65,1\% (dla

magisterskiego z socjologii rodziny i wychowania, będących podstawą prac magisterskich M. Wójcik i I. Skiby.

2 Na podstawie raportu GUS, Kobiety i mężczyźni na rynku pracy, Warszawa 2016, s. 1-20. 
Pobrane z czasopisma Annales I - Philosophy and Sociology http://philosophia.annales.umcs.pl Data: 26/04/2023 16:32:06

mężczyzn - 73,4\%). Liczba pracujących kobiet w 2015 r. wyniosła $6,9 \mathrm{mln}$. Blisko $1 / 3$ z nich pracuje w sektorze publicznym $(32,4 \%)$, pozostałe - w prywatnym (67,6\%). Najczęściej kobiety są pracownikami najemnymi (ponad 80\% pracujących), rzadziej pracują na własny rachunek (około 10\%) lub są pracodawcami (około $2 \%$ ). Blisko $11 \%$ pracuje w niepełnym wymiarze czasu pracy (ponad dwukrotnie częściej niż mężczyźni), a 27,7\% jest zatrudnionych na umowę na czas określony. $65,8 \%$ kobiet pracuje przynajmniej 40 godzin tygodniowo (dla porównania - 78,8\% mężczyzn), co wynika z częstszej pracy w niepełnym wymiarze czasu pracy. Mniej niż 40 godzin w tygodniu pracuje 27,0\% kobiet i 18,2\% mężczyzn.

Maleje natomiast stopa bezrobocia. W 2015 r. wynosiła 7,1\% dla kobiet i 6,8\% dla mężczyzn (w 2012 r. odpowiednio: 11,1\% i 9,3\%). We wszystkich grupach wiekowych bezrobocie jest wyższe wśród kobiet, z wyjątkiem grupy najstarszych (55 lat i więcej), w której bezrobocie jest nieco wyższe wśród mężczyzn.

Kwestią charakterystyczną dla sytuacji kobiet jest ich bierność zawodowa. 51\% kobiet $\mathrm{w}$ wieku 15 lat i więcej to osoby nieaktywne na rynku pracy (mężczyzn tylko 35\%). Zdecydowaną większość stanowią kobiety posiadające uprawnienia emerytalne oraz kontynuujące naukę. Jednakże istotną przyczyną ich dezaktywizacji są obowiązki rodzinne (najczęstszy powód wskazywany przez kobiety w grupach wiekowych 25-54 lata). Im starsze kobiety (w wieku produkcyjnym), tym częściej wskazują na chorobę jako przyczynę bierności zawodowej (rys. 2).

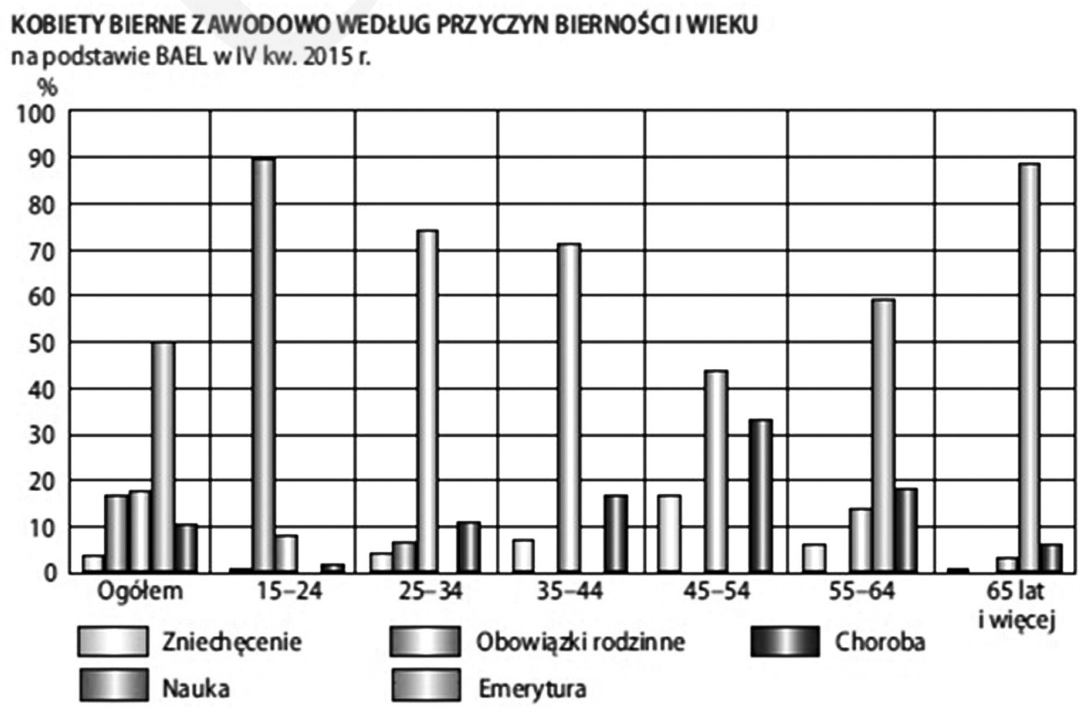

Rys. 2. Kobiety bierne zawodowo według przyczyn bierności i wieku Źródło: GUS, Kobiety i mężczyźni na rynku pracy, Warszawa 2016, s. 14. 
Pobrane z czasopisma Annales I - Philosophy and Sociology http://philosophia.annales.umcs.pl Data: 26/04/2023 16:32:06

Drugim aspektem znamiennym dla omawianego zagadnienia jest kwestia wynagrodzeń. Jak wynika z raportu GUS, wynagrodzenie kobiet było w $2014 \mathrm{r}$. o 17\% niższe niż przeciętne wynagrodzenie mężczyzn.

Mężczyźni osiągnęli wynagrodzenie o 9,1\% (o 374 zł) wyższe od średniego w skali kraju, natomiast kobiety o 9,5\% (o 390 zł) niższe. Analiza wynagrodzeń skrajnych pokazuje, że istnieją niewielkie różnice między kobietami i mężczyznami wśród pracowników o najniższych wynagrodzeniach. Natomiast wyraźne różnice można zaobserwować wśród najlepiej zarabiających. Średnie wynagrodzenie 10\% najlepiej zarabiających kobiet stanowiło $77 \%$ średniego wynagrodzenia najlepiej zarabiających mężczyzn. W przypadku 5\% najlepiej zarabiających ta relacja była jeszcze mniej korzystna i wynosiła $73 \%^{3}$.

Przytoczone dane obrazują aktywność zawodową kobiet w Polsce. Jest to z jednej strony obraz pozytywny (liczba zatrudnionych, mała stopa bezrobocia), z drugiej zaś niepokojący (niższe płace, feminizacja zawodów). Faktem jest, iż praca zawodowa kobiet jest niezbędna zarówno dla samych kobiet, jak i dla gospodarki.

\section{PRACA ZAWODOWA W OPINII KOBIET}

Praca zawodowa stanowi istotny aspekt życia kobiet. Choć jest uzależniona od ich sytuacji rodzinnej (przerywana na czas rodzenia i wychowywania dzieci) oraz rynku pracy (niestabilność zatrudnienia), kobiety chcą pracować. Dlaczego? Jakie są powody podejmowania aktywności zawodowej przez kobiety? Na to pytanie dały odpowiedź respondentki z Lublina ${ }^{4}$. W badaniu wzięły udział kobiety aktywne zawodowo, w większości zatrudnione na pełnym etacie. Połowa badanych posiada umowę o pracę na czas nieokreślony, co czwarta - umowę na czas określony, zaś $21,7 \%$ prowadzi własną działalność gospodarczą. Staż pracy kobiet jest zróżnicowany (zastosowano przedziały). Do 5 lat pracuje 35,3\% badanych, od 6 do 10 lat pracuje 30,6\%, natomiast powyżej 11 lat -34,1\%. 13,0\% badanych zajmuje stanowiska kierownicze. Blisko $2 / 3$ respondentek to osoby z wyższym wykształceniem (62,2\%), 34,1\% - z wykształceniem średnim (ogólnokształcącym i zawodowym), a 3,7\% - z zawodowym. Badane Lublinianki to kobiety w przedziale wiekowym od 20 do 60 lat (średnia - 38,41; mediana - 36,00; dominanta - 35), w zdecydowanej większości mężatki (83,9\%), posiadające dzieci - jedno $(35,6 \%)$, dwoje $(50,5 \%)$, troje lub czworo $(8,9 \%)$. Tygodniowy wymiar czasu pracy w przypadku większości respondentek wynosi 40 godzin (65,3\%), powyżej 40 godzin pracuje $21,7 \%$ badanych, zaś poniżej - 13,0\%.

3 Ibidem, s. 15, 19.

4 Badania przeprowadzono w 2016 r., zastosowano dobór celowy $(\mathrm{N}=323)$. 
Pobrane z czasopisma Annales I - Philosophy and Sociology http://philosophia.annales.umcs.pl Data: 26/04/2023 16:32:06

Czym zatem kierują się kobiety chcące pracować zawodowo? Wśród powodów można wyróżnić trzy grupy (rys. 3). Pierwsza wiąże się z oczywistymi czynnikami ekonomicznymi, jest tym samym najczęściej wskazywana. Kobiety pracują, aby zwiększyć budżet rodzinny (66,2\% wskazań), aby być niezależnymi finansowo $(64,1 \%)$, jak również by wypracować sobie emeryturę (43,9\%). Druga grupa to motywy rozwojowe (,wewnętrzne”). Kobiety pracują, aby móc się realizować $(55,1 \%)$. Ponadto wykonywana praca je interesuje $(43,4 \%)$ i chcą podnosić swoje kwalifikacje (20,7\%). Trzecia, rzadko wskazywana, grupa powodów wiąże je $\mathrm{z}$ „sytuacją społeczną, zewnętrzną". 4,0\% kobiet nie chce się czuć gorszymi od innych, a 2,5\% pracuje, ponieważ inne kobiety też pracują.

Motywacje respondentek z Lublina wpisują się w proponowane przez badaczy typy motywacji (Z. Drozdek, A. Press-Zajdowa, A. Szuman, H. Januszek, J. Sikora). Najpopularniejszy podział motywacji dzieli je na materialne i niematerialne, ale $\mathrm{z}$ badań A. Szuman wynika, iż najczęściej wskazywane są oba typy (choć w latach 60. XX w. największe znaczenie miały te o charakterze materialnym) ${ }^{5}$.

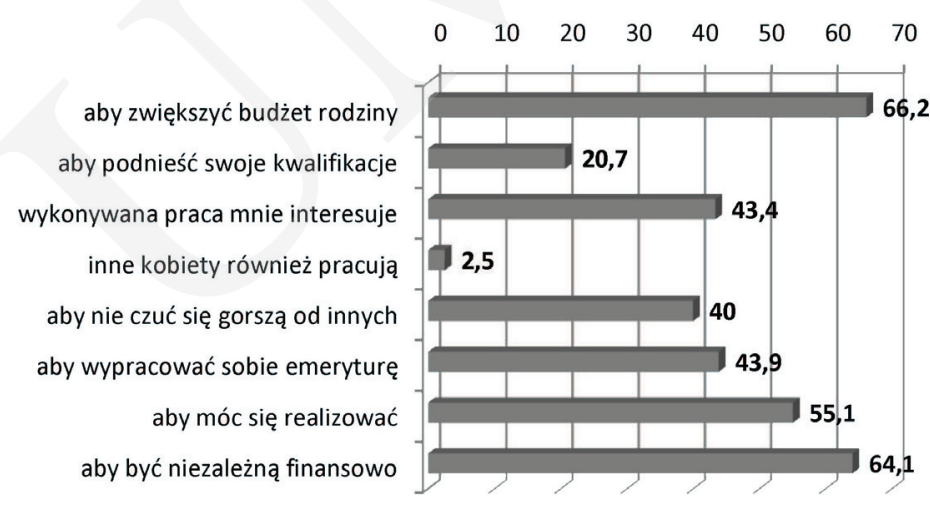

Rys. 3. Powody podejmowania pracy zawodowej przez respondentki (w \%) Źródło: badania własne (respondentki mogły wybrać trzy odpowiedzi).

Niematerialne aspekty pracy podkreślały uczestniczki badania J. Czarneckiej, K. Dzwonkowskiej-Goduli i P. Woszczyk. Z raportu badaczek wynika pozytywny wpływ pracy zawodowej:

[...] na zachowanie „komfortu psychicznego”, dobrego samopoczucia i „równowagi emocjonalnej”. Niektóre respondentki uważały wręcz, że kobiety przebywające kilka lat w domu „dziwaczeją”, nie mają dystansu do siebie i nadmiernie przejmują się drobnymi zdarzeniami, a także nie rozwijają

5 A. Szuman, Motywy pracy zawodowej matek pracujacych w fazach cyklu życia rodziny, Poznań 2001, s. 83. 
Pobrane z czasopisma Annales I - Philosophy and Sociology http://philosophia.annales.umcs.pl Data: 26/04/2023 16:32:06

się intelektualnie. [...] Praca zawodowa jest przez część kobiet postrzegana również jako forma odpoczynku i możliwości oderwania się od obowiązków domowych i rodzinnych problemów ${ }^{6}$.

Na motywację kobiet do pracy istotny wpływ ma poziom ich wykształcenia? ${ }^{7}$. Im jest wyższy, tym większe znaczenie mają motywy pozamaterialne - zainteresowanie wykonywaną pracą, dążenie do awansu, zdobywanie prestiżu i uznania, potwierdzanie własnej wartości czy chęć uczestnictwa w życiu społecznym ${ }^{8}$.

Tab. 1. Opinia na temat szacunku dla kobiet w zależności od statusu zawodowego a wiek i staż pracy respondentek

\begin{tabular}{|c|c|c|c|c|c|c|c|c|}
\hline \multirow{3}{*}{$\begin{array}{c}\text { Jaka kobieta jest bardziej ceniona } \\
\text { w polskim społeczeństwie? }\end{array}$} & \multicolumn{6}{|c|}{ Wiek } & \multicolumn{2}{|c|}{ Ogółem } \\
\hline & \multicolumn{2}{|c|}{ Do 32 lat } & \multicolumn{2}{|c|}{ 33-42 lata } & \multicolumn{2}{|c|}{ Powyżej 43 lat } & \multirow{2}{*}{$\mathrm{N}$} & \multirow{2}{*}{$\%$} \\
\hline & $\mathrm{N}$ & $\%$ & $\mathrm{~N}$ & $\%$ & $\mathrm{~N}$ & $\%$ & & \\
\hline Kobieta pracująca zawodowo & 47 & 45,2 & 70 & 60,3 & 68 & 66,0 & 185 & 57,3 \\
\hline $\begin{array}{l}\text { Gospodyni domowa, kobieta } \\
\text { niepracująca zawodowo }\end{array}$ & 0 & 0,0 & 0 & 0,0 & 1 & 1,9 & 1 & 0,3 \\
\hline Obie są cenione w równym stopniu & 26 & 25,0 & 22 & 19,0 & 17 & 16,5 & 65 & 20,1 \\
\hline Trudno powiedzieć & 31 & 29,8 & 24 & 20,7 & 17 & 16,5 & 72 & 22,3 \\
\hline \multirow[t]{4}{*}{ Ogółem } & 104 & 100,0 & 116 & 100,0 & 103 & 100,0 & 323 & 100,0 \\
\hline & \multicolumn{6}{|c|}{ Staż pracy } & \multicolumn{2}{|c|}{ Ogółem } \\
\hline & \multicolumn{2}{|c|}{ Do 5 lat } & \multicolumn{2}{|c|}{$6-10$ lat } & \multicolumn{2}{|c|}{ Powyżej 11 lat } & \multirow{2}{*}{$\mathrm{N}$} & \multirow{2}{*}{$\%$} \\
\hline & $\mathrm{N}$ & $\%$ & $\mathrm{~N}$ & $\%$ & $\mathrm{~N}$ & $\%$ & & \\
\hline Kobieta pracująca zawodowo & 55 & 49,1 & 55 & 56,7 & 73 & 67,6 & 183 & 57,7 \\
\hline $\begin{array}{l}\text { Gospodyni domowa, kobieta nie- } \\
\text { pracująca zawodowo }\end{array}$ & 0 & 0,0 & 1 & 1,0 & 0 & 0,0 & 1 & 0,3 \\
\hline Obie są cenione w równym stopniu & 26 & 23,2 & 20 & 20,6 & 18 & 16,7 & 64 & 20,2 \\
\hline Trudno powiedzieć & 31 & 27,7 & 21 & 21,6 & 17 & 15,7 & 69 & 21,8 \\
\hline Ogólem & 112 & 100,0 & 97 & 100,0 & 108 & 100,0 & 317 & 100,0 \\
\hline
\end{tabular}

Źródło: badania własne.

6 J. Czernecka, Kobieta, matka, pracownik, [w:] Mama w pracy-spoleczne uwarunkowania powrotu kobiet na rynek pracy po przerwie zwiazanej z wychowaniem dziecka, red. J. Czernecka, K. Dzwonkowska-Godula, P. Woszczyk, Łódź 2009, s. 18-19.

7 W badanej grupie kobiet zdecydowanie przeważały kobiety z wyższym poziomem wykształcenia (62,2\%), podczas gdy z zawodowym i średnim stanowiły tylko $37,8 \%$ respondentek. $\mathrm{Z}$ powodu zaistniałej dysproporcji niemożliwe było zweryfikowanie tego założenia w podjętym badaniu.

8 B. Balcerzak-Paradowska, D. Głogosz, I. Hebda-Czaplicka, B. Kołaczek, Przekształcenia własnościowe a aktywność zawodowa kobiet. Zmiany i uwarunkowania, [w:] Praca kobiet w sektorze prywatnym. Szanse i bariery, red. B. Balcerzak-Paradowska, Warszawa 2003, s. 93-155. 
Pobrane z czasopisma Annales I - Philosophy and Sociology http://philosophia.annales.umcs.pl Data: 26/04/2023 16:32:06

W ramy niematerialnych motywów wpisuje się również opinia społeczna na temat kobiet pracujących i niepracujących. $Z$ badań CBOS-u wynika, iż w Polsce funkcjonują dwa stanowiska. Ponad 2/5 ankietowanych (44\%) uważa, iż większym szacunkiem społecznym cieszą się kobiety pracujące zawodowo; tyle samo sądzi jednak, że kobiety - bez względu na ich sytuację zawodową - są poważane tak samo. Tylko 5\% badanych darzy większym szacunkiem gospodynie domowe zajmujące się wyłącznie prowadzeniem domu i opieką nad dziećmi ${ }^{9}$. A jaką mają opinię na ten temat badane Lublinianki? Ich zdaniem bardziej cenione są kobiety pracujące zawodowo (57,3\% wskazań). Tylko co piąta uważa, że obie (pracująca i niepracująca) są cenione w równym stopniu (tab. 1).

Opinię tę różnicuje wiek respondentek. Im starsze, tym częściej wskazują na aktywność zawodową, dzięki której kobiety są cenione w społeczeństwie. Młodsze zaś (do 32 lat) częściej niż starsze (powyżej 43 lat) twierdzą, że i pracujące, i niepracujące są jednakowo cenione (odpowiednio 23,2\% i 16,7\%). Opinię Lublinianek podobnie różnicuje staż pracy. Im dłuższy, tym więcej wskazań na pogląd, iż kobiety pracujące zawodowo są bardziej cenione w społeczeństwie. Być może opinia ta wynika z własnych doświadczeń respondentek lub z obserwacji życia społecznego. Zaskakująca jest natomiast dysproporcja w odpowiedziach w porównaniu z badaniem ogólnopolskim.

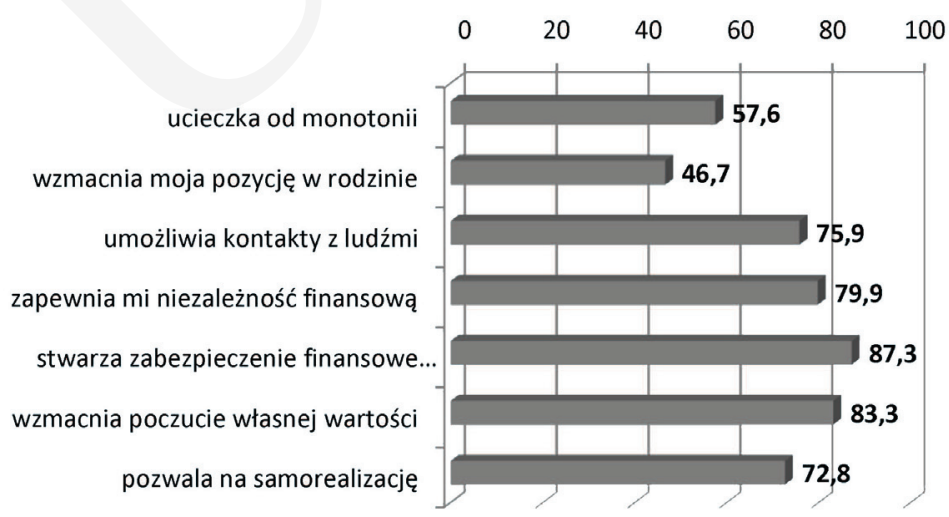

Rys. 4. Opinia na temat korzyści wynikających z pracy zawodowej (w \%, N=323) Źródło: badania własne (na wykresie przestawiono tylko odpowiedzi twierdzące).

Skoro respondentki podkreślają znaczenie aktywności zawodowej, ponadto w większości są zadowolone ze swojej pracy zawodowej $(87,3 \%$ wskazań twierdzących), wobec tego jakie korzyści daje im praca zawodowa? Ponownie

9 Kobieta pracująca. Komunikat CBOS, Warszawa 2013, s. 3. 
Pobrane z czasopisma Annales I - Philosophy and Sociology http://philosophia.annales.umcs.pl Data: 26/04/2023 16:32:06

znaczenie mają dwa czynniki - ekonomiczny i samorealizacji (rys. 4). Praca zawodowa zapewnia przede wszystkim zabezpieczenie finansowe zarówno rodzinie (87,3\% wskazań), jak i samym kobietom, dając im niezależność finansową (79,9\%). Wzmacnia też poczucie własnej wartości kobiety $(83,3 \%)$, pozwala na samorealizację (72,8\%), umożliwia kontakty z ludźmi (75,9\%) i jest ucieczką od monotonii (57,6\%). Na podobne korzyści z aktywności zawodowej wskazały uczestniczki badania A. Kwak i G. Pascall. Z badań autorek wynika, iż:

[...] praca zawodowa podnosi poczucie własnej wartości kobiety, przynosi „oddech” po monotonii obowiązków domowych, pozwala na spojrzenie z pewnego dystansu na sprawy domowe, stwarza okazję do kontaktów społecznych, ułatwia poruszanie się w środowisku pozarodzinnym. Praca zawodowa wyraża także bardziej perspektywiczną korzyść - zabezpiecza kobietę przed pozostaniem z ,pustymi rękoma”, gdy dzieci dorosną i odejdą z domu ${ }^{10}$.

Respondentki z Lublina wskazały również na inną istotną kwestię, mianowicie na korzyść związaną ze zmianą pozycji kobiety w rodzinie. Zdaniem blisko połowy badanych kobiet (46,7\%) fakt, że pracują zawodowo, tę pozycję wzmacnia. Wyjaśnienie tego wpływu odnosi się do czynnika ekonomicznego, ale w innym znaczeniu niż poprawa sytuacji materialnej rodziny. Według A. Kwak i G. Pascall, których respondentki także ten fakt podkreślały, owo wzmocnienie pozycji kobiety ma miejsce, ponieważ praca zawodowa współtworzy budżet domowy, daje niezależność finansową i niezależność od męża oraz poczucie bezpieczeństwa i pewność, że kobieta da sobie radę w życiu. Tym samym podnosi prestiż w środowisku rodzinnym, wyrównuje pozycję oraz prawa męża i żony w rodzinie, zmuszając męża do partnerstwa ${ }^{11}$. Respondentki A. Kwak i G. Pascall (w swobodnych wywiadach, choć były to nieliczne wskazania) zwróciły także uwagę na odwrotną sytuację osłabienie pozycji kobiety w rodzinie. Powód wiąże się z mniejszą ilością czasu i energii poświęcanej dla domu i życia rodzinnego. Skutkiem jest zaniedbany dom, niedopilnowane dzieci czy zakłócone relacje z mężem ${ }^{12}$. Na takie problemy kobiety rzadko wskazywały, co świadczy o dużym znaczeniu pracy zawodowej dla ich samooceny.

Czy w związku z tym badane kobiety zrezygnowałyby z pracy zawodowej, gdyby ich mąż/partner zarabiał wystarczająco na utrzymanie rodziny? 2/3 ankietowanych Lublinianek nie podjęłoby takiej decyzji, choć blisko 1/4 odpowiedziała twierdząco, przy czym częściej spośród młodszych kobiet (blisko 1/3 respondentek

10 A. Kwak, G. Pascall, Kobiety na rynku pracy - bariery ptci, „,Roczniki Socjologii Rodziny" 2005, nr 16, s. 18.

11 Ibidem, s. 22.

12 Ibidem, s. 21. 
Pobrane z czasopisma Annales I - Philosophy and Sociology http://philosophia.annales.umcs.pl Data: 26/04/2023 16:32:06

do lat 32) (tab. 2). Być może opinia ta wynika z faktu posiadania dzieci i zwiększonych obowiązków rodzinnych.

Podobnie rozkład odpowiedzi przedstawia się w odniesieniu do stażu pracy respondentek (tab. 2). Im jest dłuższy, tym więcej odpowiedzi negatywnych (kobiety nie chcą rezygnować z pracy). Być może wraz z liczbą przepracowanych lat rośnie znaczenie czynników niematerialnych - realizacja ambicji, rozwój osobisty, zainteresowanie pracą czy po prostu spełnianie się w niej. Z tego względu kobiety nie chcą rezygnować z pracy zawodowej i spełniać się tylko w roli matki i gospodyni.

Tab. 2. Opinia na temat ewentualnej rezygnacji z pracy zawodowej a wiek i staż pracy respondentek

\begin{tabular}{|c|c|c|c|c|c|c|c|c|}
\hline \multirow{3}{*}{$\begin{array}{l}\text { Czy zrezygnowałaby Pani z pracy } \\
\text { zawodowej na rzecz zajęcia się } \\
\text { w większym stopniu domem } \\
\text { i dziećmi, gdyby Pani mąż/part- } \\
\text { ner zarabiał wystarczająco } \\
\text { na utrzymanie rodziny? }\end{array}$} & \multicolumn{6}{|c|}{ Wiek } & \multicolumn{2}{|c|}{ Ogółem } \\
\hline & \multicolumn{2}{|c|}{ Do 32 lat } & \multicolumn{2}{|c|}{ 33-42 lata } & \multicolumn{2}{|c|}{ Powyżej 43 lat } & \multirow{2}{*}{$\mathrm{N}$} & \multirow{2}{*}{$\%$} \\
\hline & $\mathrm{N}$ & $\%$ & $\mathrm{~N}$ & $\%$ & $\mathrm{~N}$ & $\%$ & & \\
\hline Tak & 33 & 31,7 & 28 & 24,1 & 18 & 17,5 & 79 & 24,5 \\
\hline Nie & 59 & 56,8 & 77 & 66,4 & 75 & 72,8 & 211 & 65,3 \\
\hline Trudno powiedzieć & 12 & 11,5 & 11 & 9,5 & 10 & 9,7 & 33 & 10,2 \\
\hline \multirow[t]{4}{*}{ Ogółem } & 104 & 100,0 & 116 & 100,0 & 103 & 100,0 & 323 & 100,0 \\
\hline & \multicolumn{6}{|c|}{ Staż pracy } & \multicolumn{2}{|c|}{ Ogółem } \\
\hline & \multicolumn{2}{|c|}{ Do 5 lat } & \multicolumn{2}{|c|}{$6-10$ lat } & \multicolumn{2}{|c|}{ Powyżej 11 lat } & \multirow{2}{*}{$\mathrm{N}$} & \multirow{2}{*}{$\%$} \\
\hline & $\mathrm{N}$ & $\%$ & $\mathrm{~N}$ & $\%$ & $\mathrm{~N}$ & $\%$ & & \\
\hline Tak & 34 & 30,4 & 24 & 24,7 & 20 & 18,5 & 78 & 24,6 \\
\hline $\mathrm{Nie}$ & 63 & 56,2 & 68 & 70,1 & 76 & 70,4 & 207 & 65,3 \\
\hline Trudno powiedzieć & 15 & 13,4 & 5 & 5,2 & 12 & 11,1 & 32 & 10,1 \\
\hline Ogółem & 112 & 100,0 & 97 & 100,0 & 108 & 100,0 & 317 & 100,0 \\
\hline
\end{tabular}

Źródło: badania własne.

Również ogólnopolskie badania CBOS-u pokazują stanowisko kobiet w tej kwestii, przy czym nie jest ono tak jednoznaczne, jak lubelskich respondentek. Choć rośnie odsetek kobiet, które nie zrezygnowałyby z pracy przy zadowalających zarobkach męża (2006 r. - 34\%, 2013 r. - 44\%), to nadal ponad połowa podjęłaby taką decyzję (2006 r. - 58\%, 2013 r. - 52\%). Kontynuowanie pracy zawodowej częściej deklarują kobiety z wyższym poziomem wykształcenia, zajmujące wysokie i ,średnie” stanowiska lub pracujące ,na własny rachunek” oraz dobrze oceniające swoją sytuację materialną ${ }^{13}$. 
Pobrane z czasopisma Annales I - Philosophy and Sociology http://philosophia.annales.umcs.pl Data: 26/04/2023 16:32:06

$112 \quad$ Małgorzata Szyszka

Praca zawodowa stanowi niewątpliwie ważną część życia kobiet. Jest źródłem osobistej satysfakcji, daje poczucie własnej wartości, zapewnia prestiż i uznanie oraz nadaje życiu sens ${ }^{14}$. Zrozumiały jest zatem fakt podejmowania aktywności zawodowej przez kobiety, również te posiadające dzieci, mimo spodziewanych trudności i obaw.

\section{DYSKRYMINACJA KOBIET W SFERZE ZAWODOWEJ - PUNKT WIDZENIA KOBIET}

Mimo że praca zawodowa stanowi niemal integralną część ludzkiego życia, sfera ta nie jest wolna od trudności i barier, z którymi muszą się mierzyć kobiety w toku swej aktywności zawodowej. Owe bariery dotyczą różnych kwestii - zajmowanych stanowisk, zawodów, awansu czy wynagrodzeń. Kobiety spotykają się z różnymi przejawami nierówności płci i dyskryminacji. Jest to zjawisko segregacji zawodowej zarówno poziomej, jak i pionowej ${ }^{15}$. Ze zjawiskiem segregacji poziomej wiąże się stopień feminizacji lub maskulinizacji zawodów. Do najbardziej sfeminizowanych sekcji zalicza się: ochronę zdrowia, działalność finansową, zakwaterowanie i gastronomię oraz edukację, zaś do zmaskulinizowanych - budownictwo i górnictwo ${ }^{16}$. Częściowo zjawisko to można tłumaczyć innym - segregacją edukacyjną. Kobiety i mężczyźni kształcą się w różnych dziedzinach, co zmniejsza ich późniejsze możliwości wyboru zawodu ${ }^{17}$. Z kolei chęć podjęcia pracy przez kobietę w zawodach tzw. męskich często kończy się porażką już na etapie rekrutacji. Z zagadnieniem segregacji poziomej wiąże się również zjawisko określane mianem „lepkiej podłogi” (sticky floor), symbolizujące wykonywanie przez kobiety zawodów o niewielkich możliwościach awansu zawodowego, niskim statusie społecznym i niskich zarobkach (np. pielęgniar$\mathrm{ka}$, sekretarka), choć wymagają odpowiednich kwalifikacji ${ }^{18}$. Z kolei pionowa segregacja zawodowa oznacza dysproporcję między liczbą kobiet i mężczyzn pracujących na stanowiskach decyzyjnych na niekorzyść kobiet, mimo porównywalnego poziomu wykształcenia ${ }^{19}$. To zjawisko określa termin ,szklany sufit”

14 M. Ołdak, Praca zawodowa w życiu polskich kobiet: jako wartość i doświadczenie, [w:] Wyksztatcenie i kwalifikacje kobiet a ich sytuacja na rynku pracy, red. G. Firlit-Fesnak, Warszawa 2008, s. 150-156.

15 H. Domański, Zadowolony niewolnik idzie do pracy, Warszawa 1999, s. 29.

16 B. Kalinowska-Sufinowicz, Polityka społeczno-gospodarcza państwa wobec pracy kobiet, Poznań 2013, s. 144.

17 A. Matysiak, T. Słoczyński, A. Baranowska, Kobiety i mężczyźni na rynku pracy, [w:] Zatrudnienie w Polsce 2008. Praca w cyklu życia, red. M. Bukowski, Warszawa 2010, s. 126.

18 B. Kalinowska-Sufinowicz, op. cit., s. 144.

19 Ibidem, s. 146. 
Pobrane z czasopisma Annales I - Philosophy and Sociology http://philosophia.annales.umcs.pl Data: 26/04/2023 16:32:06

(glass ceiling) $^{20}$. Pomimo dominacji liczebnej kobiet w zawodach związanych z usługami, administracją publiczną i pomocą społeczną, zajmują one raczej stanowiska niższego rzędu. Kobiety zresztą same niechętnie ubiegają się o stanowiska kierownicze, gdyż są przekonane o swojej słabszej pozycji na rynku pracy, a te, które je sprawują, ponoszą często wyższe koszty ich osiągnięcia niż mężczyźni.

Jak na kwestię sytuacji kobiet w odniesieniu do awansu i zajmowania stanowiska kierowniczego zapatrują się respondentki z Lublina? Ich zdaniem kobiety mają mniejsze szanse na awans zawodowy, lecz opinię tę podziela co druga ankietowana (51,7\%). Częściej uważają tak kobiety z dłuższym stażem zawodowym (powyżej 6 lat pracy - ponad 55\% wskazań) (rys. 5). Natomiast co trzecia respondentka z krótszym stażem zawodowym (poniżej 5 lat) jest zdania, że kobiety i mężczyźni mają takie same szanse na awans zawodowy. Być może na opinię pań z krótszym stażem i zarazem młodszych ma wpływ fakt, że nie zetknęły się jeszcze z „przykrymi” sytuacjami na ścieżce zawodowej, a być może fakt coraz częściej stosowanych rozwiązań legislacyjnych w zakresie równouprawnienia płci, które niwelują owe „przykre” okoliczności. Ogólnopolski odbiór sytuacji kobiet jest analogiczny. Panuje przekonanie, że kobiety mają mniejsze szanse na awans zawodowy (56\% wskazań), ale częściej taki pogląd mają kobiety niż mężczyźni (odpowiednio 63\% i 49\%). O równości szans awansu obu płci przekonana jest nieco ponad $1 / 4$ badanych (29\%), a o przewadze kobiet - zaledwie co jedenasty respondent $(9 \%)^{21}$.

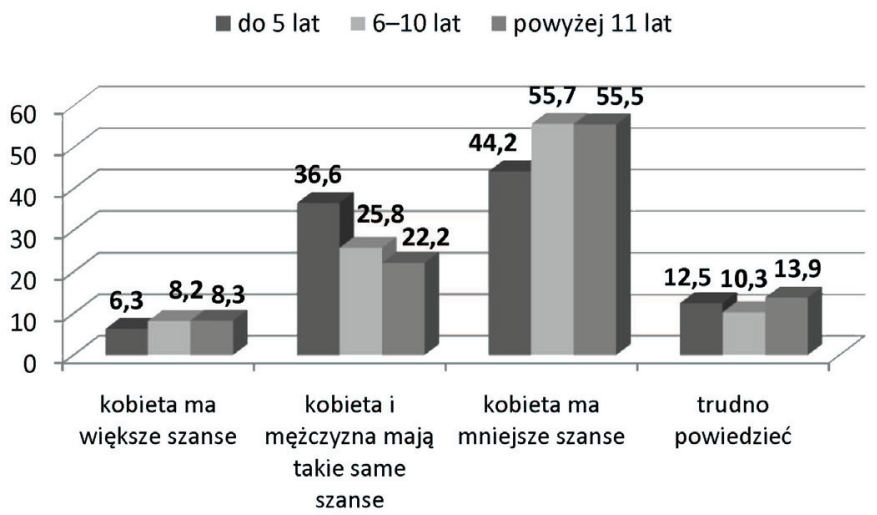

Rys. 5. Opinia na temat szans na awans zawodowy kobiet i mężczyzn a staż pracy respondentek $(\mathrm{w} \%, \mathrm{~N}=317)$

Źródło: badania własne.

20 Zob. Szklany sufit. Bariery i ograniczenia pracy kobiet, red. A. Titkow, Warszawa 2003.

21 Kobieta pracujaca..., s. 6-7. 
Pobrane z czasopisma Annales I - Philosophy and Sociology http://philosophia.annales.umcs.pl Data: 26/04/2023 16:32:06

W badanej grupie kobiet tylko 13,0\% zajmuje stanowiska kierownicze. Czy zatem, gdyby padła propozycja objęcia wyższego kierowniczego stanowiska, badane Lublinianki zgodziłyby się je objąć? Pytanie to okazało się trudne dla respondentek, czego skutkiem był brak danych, a co piąta respondentka „uciekła” w odpowiedź trudno powiedzieć. Pozostałe natomiast niemal w takim samym stopniu odpowiedziały twierdząco (40,2\% wskazań) i przecząco (39,6\%). Różnice zdań determinuje wiek badanych kobiet (rys. 6). Zgodę na objęcie stanowiska kierowniczego częściej wyrażały młodsze respondentki (do 32 lat aż $45,2 \%$ wskazań, a w przedziale wieku 33-42 lata-36,2\%). Starsze respondentki częściej nie zgodziłyby się (w kategorii wieku powyżej 46 lat - 33,9\% wskazań) lub miały trudności z ustosunkowaniem się do tej kwestii (aż co druga respondentka w wieku powyżej 43 lat - 51,6\%).

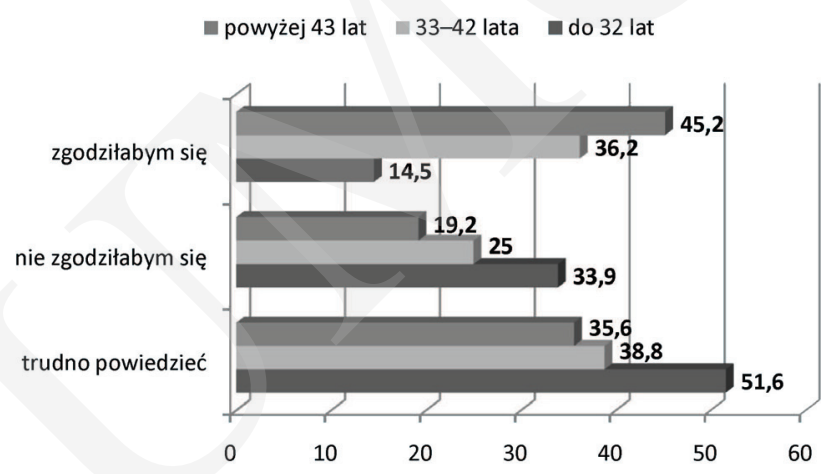

Rys. 6. Opinia na temat ewentualnego zajmowania stanowiska kierowniczego a wiek respondentek $(\mathrm{w} \%, \mathrm{~N}=243)$

Źródło: badania własne.

Decyzja o zajęciu stanowiska kierowniczego zależy od wielu czynników: osobowościowych, rodzinnych czy wynikających ze stosunku pracy i relacji w niej panujących. Jakie trudności dostrzegają kobiety w osiągnięciu awansu w pracy? Dwie najczęściej wskazywane wiążą się z cechami charakteru samych kobiet. $63,7 \%$ respondentek wskazało na lęk przed podjęciem ryzyka, zaś $61,2 \%$ - na brak wiary w siebie (rys. 7). Jest to, jak się wydaje, największa przeszkoda tkwiąca w samych kobietach. B. Kalinowska-Sufinowicz pisze o zjawisku ,autostereotypizacji” przejawiającym się w niższej samoocenie kobiet w roli pracownicy i z tego względu formułowaniu niższych oczekiwań odnośnie do awansu zawodowego i oczekiwań płacowych ${ }^{22}$. P. Sztompka określa to zjawisko efektem „samospełniającej się prognozy". Według niego:

22 B. Kalinowska-Sufinowicz, op. cit., s. 155. 
[...] kulturowe definicje ról męskich i kobiecych można traktować jako swoiste przesądy. Skoro uznajemy, że kobiety są predysponowane do pewnych zawodów, a nie nadają się do innych, w wyniku autoselekcji i selektywnej rekrutacji kobiety podejmują w większości zawody kobiece. I ten fakt zaczyna służyć umocnieniu przyjętych definicji „kobiecości” i „męskości”. [...] Skoro w pewnych zawodach jest mniej kobiet, to może nie leżą one w ich charakterze. A więc może nie warto o takie zawody zabiegać - myślą kobiety, może nie trzeba ich na takich stanowiskach zatrudniać - myślą mężczyźni ${ }^{23}$.

Brak wiary w siebie to jednocześnie chyba najtrudniejsza bariera, ponieważ zmiana samopostrzegania kobiet, podnoszenie ich niskiej samooceny (jako „gorszego pracownika", który nie poradzi sobie z wyzwaniami) utrwalanej przez lata, jest rzeczywiście wyzwaniem.

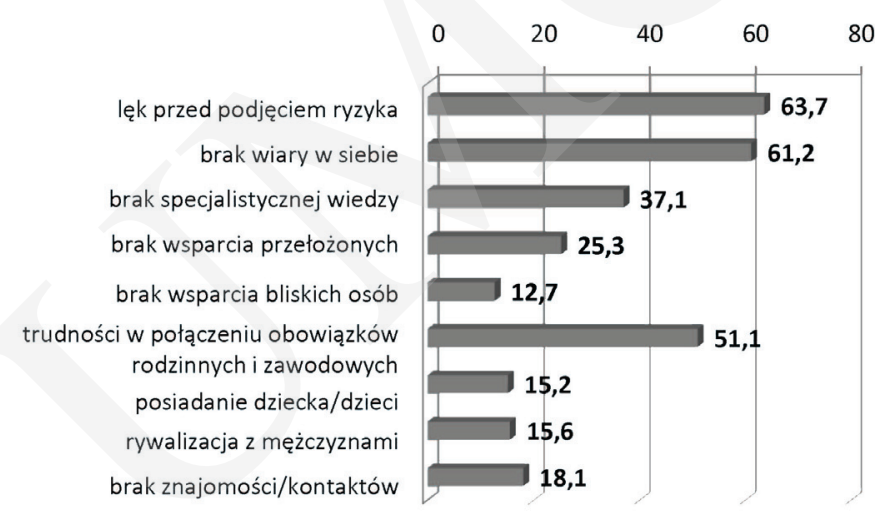

Rys. 7. Opinia kobiet na temat czynników utrudniających awans na stanowisko kierownicze ( $\mathrm{w} \%$ )

Źródło: badania własne (respondentki mogły wybrać trzy odpowiedzi).

Połowa respondentek wskazuje ponadto na trudności w połączeniu obowiązków rodzinnych i zawodowych (51,1\% wskazań), a 15,2\% - posiadanie dziecka/ dzieci. Zwykle awans wiąże się z koniecznością poświęcenia większej ilości czasu w pracy oraz byciem dyspozycyjnym i elastycznym. Niestety, ,posiadanie rodziny oraz konieczność sprawowania opieki nad jej członkami rodzi konflikt czasu i dyspozycyjności" ${ }^{24}$. Jak wskazują badania, respondentki mają trudności w godzeniu obowiązków i czasem jedne z nich wykonują kosztem drugich (40\%), a prawie $6 \%$ badanych kobiet wskazuje wprost na częste problemy w godzeniu życia rodzinnego z zawodowym ${ }^{25}$. Kobiety są zdecydowanie bardziej obciążone

23 P. Sztompka, Socjologia. Analiza społeczeństwa, Kraków 2002, s. 349-350.

24 A. Kwak, Rodzina i jej przemiany, Warszawa 1994, s. 37.

25 Blisko połowie badanych (48,7\%) jednak się to udaje. Zob. M. Szyszka, Kobiety między 
Pobrane z czasopisma Annales I - Philosophy and Sociology http://philosophia.annales.umcs.pl Data: 26/04/2023 16:32:06

116 Małgorzata Szyszka

i odczuwają znacznie większe trudności związane $\mathrm{z}$ wypełnianiem funkcji rodzicielskiej, prowadzeniem gospodarstwa domowego i wypełnianiem zadań pracownika niż mężczyźni. Kobiety poświęcają bowiem istotnie więcej czasu na prace domowe i opiekę nad dziećmi ${ }^{26}$.

Obiektywną przeszkodą w objęciu wyższego stanowiska w pracy może być również brak specjalistycznej wiedzy (37,1\% wskazań). Kobiety wskazały ponadto na brak wsparcia zarówno ze strony bliskich (12,7\%), jak i, znacznie częściej, przełożonych (co czwarta respondentka). 15,6\% badanych zaakcentowało wprost rywalizację z mężczyznami. Kobiety mają więc świadomość i swoich słabości, i barier „zewnętrznych” utrudniających im odważne decyzje w kwestii awansów.

Tab. 3. Opinia na temat dysproporcji zarobków kobiet i mężczyzn a staż pracy respondentek

\begin{tabular}{|c|c|c|c|c|c|c|c|c|}
\hline \multirow{3}{*}{$\begin{array}{c}\text { Czy, Pani zdaniem, kobieta wykonująca } \\
\text { ten sam zawód i mająca taki sam po- } \\
\text { ziom wykształcenia jak mężczyzna, } \\
\text { zarabia na ogół: }\end{array}$} & \multicolumn{6}{|c|}{ Staż pracy } & \multicolumn{2}{|c|}{ Ogółem } \\
\hline & \multicolumn{2}{|c|}{ Do 5 lat } & \multicolumn{2}{|c|}{$6-10$ lat } & \multicolumn{2}{|c|}{$\begin{array}{c}\text { Powyżej } \\
11 \text { lat }\end{array}$} & \multirow[t]{2}{*}{$\mathrm{N}$} & \multirow[t]{2}{*}{$\%$} \\
\hline & $\mathrm{N}$ & $\%$ & $\mathrm{~N}$ & $\%$ & $\mathrm{~N}$ & $\%$ & & \\
\hline Więcej & 3 & 2,7 & 2 & 2,1 & 3 & 2,8 & 8 & 2,5 \\
\hline Tyle samo, co mężczyzna & 15 & 13,4 & 11 & 11,3 & 12 & 11,1 & 38 & 12,0 \\
\hline Mniej & 61 & 54,5 & 67 & 69,1 & 64 & 59,3 & 192 & 60,6 \\
\hline Trudno powiedzieć & 33 & 29,5 & 17 & 17,5 & 29 & 26,9 & 79 & 24,9 \\
\hline Ogólem & 112 & 100,0 & 97 & 100,0 & 108 & 100,0 & 317 & 100,0 \\
\hline
\end{tabular}

Źródło: badania własne.

Z segregacją zawodową łączy się także wspomniana już kwestia nierówności wynagrodzeń między płciami. Kobiety w Polsce otrzymują niższe płace od mężczyzn ${ }^{27}$, choć są lepiej wykształcone. Feminizacja zawodów (i utrzymywanie się w nich niskich płac) oraz okresy przerw w pracy zawodowej kobiet, związane z wykorzystaniem urlopu macierzyńskiego i wychowawczego, istotnie sprzyjają powstawaniu nierówności płacowych. Jak tę sytuację postrzegają badane kobiety?

domem a praca. Oczekiwane wsparcie i instrumenty polityki rodzinnej na rzecz godzenia ról zawodowych z rodzinnymi, „Studia nad Rodziną” 2015, nr 36, s. 143.

26 Zob. A. Titkow, D. Duch-Krzystoszek, B. Budrowska, Nieodpłatna praca kobiet. Mity, realia, perspektywy, Warszawa 2010.

27 Zob. Z. Jacukowicz, Zróżnicowanie płac w Polsce, w krajach Unii Europejskiej i w USA, Warszawa 2000; B. Kalinowska-Nawrotek, Dyskryminacja kobiet w sferze pracy i płacy, [w:] Przedsiębiorstwo i jego otoczenie. Przemiany i perspektywy, red. A. Manikowski, A. Psyk, t. 2, Warszawa 2007. 
Pobrane z czasopisma Annales I - Philosophy and Sociology http://philosophia.annales.umcs.pl Data: 26/04/2023 16:32:06

Czy dostrzegają dysproporcje w zarobkach między płciami? Okazuje się, że tak (tab. 3). 60,6\% ankietowanych uważa, że kobiety zarabiają mniej od mężczyzn w sytuacji wykonywania tego samego zawodu, choć blisko co czwarta nie umiała odpowiedzieć na to pytanie. Częściej tę dysproporcję zauważają respondentki z dłuższym stażem pracy $(69,1 \%$ wskazań kobiet ze stażem pracy w przedziale 6-10 lat, 59,3\% - ze stażem powyżej 11 lat pracy). Tylko średnio co dziesiąta badana uważa, że kobiety zarabiają tyle samo, co mężczyźni.

Próbę wyjaśnienia zjawiska różnic w płacach ze względu na płeć podjęła E. Lisowska. Biorąc pod uwagę makroekonomiczny punkt widzenia (gospodarki jako całości), uważa, że na różnice w przeciętnych płacach kobiet i mężczyzn składają się:

- segregacja zawodowa, czyli nadmierne skupienie przedstawicieli jednej płci w określonych zawodach, branżach gospodarki lub na niektórych stanowiskach,

- bardzo niski udział kobiet na najwyższych, najlepiej płatnych stanowiskach kierowniczych, w tym w szczególności w największych firmach (np. bankach),

- stereotypy dotyczące postrzegania i wartościowania kwalifikacji kobiet jako gorszych niż kwalifikacje i umiejętności mężczyzn, czyli androcentryczny model rynku pracy,

- brak krajowych mechanizmów, które równoważyłyby negatywny wpływ czynników kulturowych, promowały partnerstwo w rodzinie i kontrolowały przestrzeganie zasady równego traktowania kobiet i mężczyzn na rynku pracy i w społeczeństwie ${ }^{28}$.

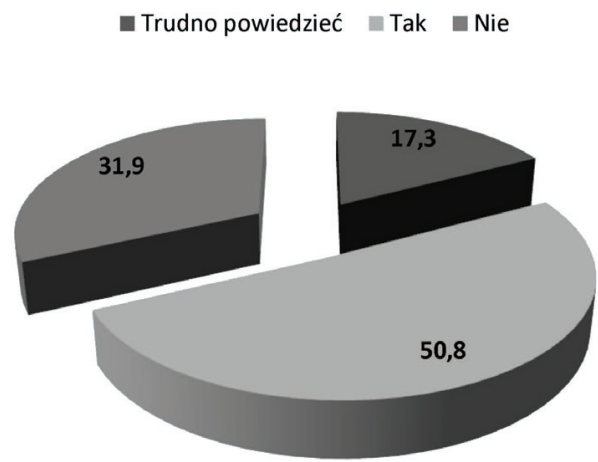

Rys. 8. Opinia na temat dyskryminacji kobiet w społeczeństwie (w \%)

Źródło: badania własne.

28 E. Lisowska, Równouprawnienie kobiet i mężczyzn w społeczeństwie, Warszawa 2010, s. $144-145$. 
Pobrane z czasopisma Annales I - Philosophy and Sociology http://philosophia.annales.umcs.pl Data: 26/04/2023 16:32:06

W Polsce toczy się dyskusja o równouprawnieniu płci w sferze zawodowej, trwają prace legislacyjne, wprowadzane są kolejne rozwiązania na rzecz równego traktowania kobiet. Czy tym samym badane kobiety dostrzegają zjawisko dyskryminowania kobiet w społeczeństwie? Co druga badana Lublinianka (50,8\%) jest zdania, że kobiety mają mniejsze szanse i możliwości w życiu niż mężczyźni. Blisko co trzecia (31,9\%) natomiast tak nie uważa. 17,3\% kobiet nie ma wyrobionej opinii na ten temat albo świadomości dyskryminującego charakteru działań pracodawcy. Badanie ogólnopolskie CBOS-u z kolei przedstawia odmienny rozkład odpowiedzi - niemal tyle samo Polaków odpowiada twierdząco (44\%), ile jest przeciwnego zdania (46\%). Opinię różnicuje płeć. Kobiety zdecydowanie częściej twierdzą, że mają mniejsze szanse ${ }^{29}$ (ponad połowa z nich zgadza się z tezą o dyskryminacji swojej płci) ${ }^{30}$.

$\mathrm{Z}$ analizy form dyskryminacji zawodowej, z jakimi zetknęły się bezpośrednio badane Lublinianki, wynika, iż rozpatrywane przypadki mają raczej dyskusyjny charakter (tab. 4). W większości sytuacji kobiety miały podzielone zdanie. Do takich sytuacji, w których odpowiedzi potwierdzające i przeczące są zbliżone procentowo, należą: nierówne traktowanie ze względu na posiadanie dzieci lub ciążę (43,0\% wskazań potwierdzających, ale blisko $40 \%$ kobiet z taką sytuacją się nie spotkało), brak dostępu do niektórych zawodów (40,2\% odpowiedzi potwierdzających i 39,6\% przeczących - częściej młodsze respondentki), mniejsze szanse na awans zawodowy (36,5\% potwierdzających i 41,8\% przeczących - częściej młodsze respondentki), a także otrzymywanie niższych wynagrodzeń od wynagrodzeń mężczyzn (39,9\% potwierdzających - częściej starsze respondentki, i 44,0\% przeczących). W zasadzie można uznać, że badane kobiety wskazały tylko na jedną sytuację, z którą bezpośrednio się zetknęły, a którą traktują jako formę dyskryminacji. Mianowicie wskazały na fakt, że więcej ofert pracy jest skierowanych do mężczyzn (49,2\% wskazań, częściej młodsze respondentki). Nie spotkały się natomiast (albo takie sytuacje miały rzadziej miejsce) z takimi przejawami dyskryminacji, jak: nierówne traktowanie w pracy (56,0\% wskazań), lekceważący stosunek pracodawcy do kobiet $(72,8 \%)$, trudności w awansie na stanowiska kierownicze $(54,8 \%)$ oraz większe obciążenie obowiązkami zawodowymi $(58,2 \%)$. Podkreślenia wymaga jednak fakt, że niemal w każdym przypadku około 1/5 kobiet miała trudności ze zdefiniowaniem omawianych sytuacji jako form dyskryminacji.

29 Sytuację tę dobrze obrazuje wypowiedź respondentki: „[...] jak kobieta chce się realizować zawodowo, ma na to szansę, ale musi walczyć, i to jest cały czas taka walka, udowadnianie, że jestem lepsza niż mężczyzna albo tak samo dobra. Często jest to powiedzenie słynne, że to dziewczynki się uczą, ale to mężczyźni zostają dyrektorami”. Zob. A. Woźniakowska, J. Korona, Raport z badania realizowanego w ramach projektu ,Mamy pracujace mamy”, Kielce 2011, s. 31.

30 Równouprawnienie ptci. Komunikat CBOS, Warszawa 2013, s. 5-6. 
Pobrane z czasopisma Annales I - Philosophy and Sociology http://philosophia.annales.umcs.pl Data: 26/04/2023 16:32:06

Aktywność zawodowa w opinii pracujących kobiet

Tab. 4. Formy dyskryminacji w życiu zawodowym, z którymi zetknęły się respondentki

\begin{tabular}{|c|c|c|c|c|c|}
\hline \multirow{3}{*}{\multicolumn{2}{|c|}{$\begin{array}{l}\text { Z jakimi formami dyskryminacji kobiet zetknęła się Pani } \\
\text { w swoim życiu zawodowym? }\end{array}$}} & \multicolumn{3}{|c|}{ Wiek } & \multirow{3}{*}{ Ogółem } \\
\hline & & \multirow{2}{*}{$\begin{array}{c}\begin{array}{c}\text { Do } 32 \\
\text { lat }\end{array} \\
\mathrm{N}=104\end{array}$} & \multirow{2}{*}{$\begin{array}{c}33-42 \\
\text { lata } \\
\mathrm{N}=116\end{array}$} & \multirow{2}{*}{$\begin{array}{c}\text { Powyżej } \\
43 \text { lat } \\
\mathrm{N}=103\end{array}$} & \\
\hline & & & & & \\
\hline \multirow{3}{*}{$\begin{array}{l}\text { Niższe wynagrodzenie od } \\
\text { wynagrodzenia mężczyzn }\end{array}$} & Tak & 33,7 & 43,1 & 42,7 & 39,9 \\
\hline & $\mathrm{Nie}$ & 51,9 & 40,5 & 39,8 & 44,0 \\
\hline & Trudno powiedzieć & 14,4 & 16,4 & 17,5 & 16,1 \\
\hline \multirow{3}{*}{ Nierówne traktowanie w pracy } & Tak & 22,1 & 32,8 & 25,2 & 26,9 \\
\hline & Nie & 67,3 & 50,9 & 50,5 & 56,0 \\
\hline & Trudno powiedzieć & 10,6 & 16,4 & 24,3 & 17,0 \\
\hline \multirow{3}{*}{$\begin{array}{l}\text { Więcej ofert pracy skierowanych do } \\
\text { mężczyzn }\end{array}$} & Tak & 53,8 & 50,0 & 43,7 & 49,2 \\
\hline & Nie & 34,6 & 31,0 & 27,2 & 31,0 \\
\hline & Trudno powiedzieć & 11,5 & 19,0 & 29,1 & 19,8 \\
\hline \multirow{3}{*}{$\begin{array}{l}\text { Nierówne traktowanie ze względu } \\
\text { na posiadanie dzieci lub ciążę }\end{array}$} & Tak & 45,2 & 44,8 & 38,8 & 43,0 \\
\hline & Nie & 44,2 & 37,1 & 38,8 & 39,9 \\
\hline & Trudno powiedzieć & 10,6 & 18,1 & 22,3 & 17,0 \\
\hline \multirow{3}{*}{$\begin{array}{l}\text { Mniejsze szanse na awans } \\
\text { zawodowy }\end{array}$} & Tak & 29,8 & 44,8 & 34,0 & 36,5 \\
\hline & Nie & 54,8 & 32,8 & 38,8 & 41,8 \\
\hline & Trudno powiedzieć & 15,4 & 22,4 & 27,2 & 21,7 \\
\hline \multirow{3}{*}{$\begin{array}{l}\text { Lekceważący stosunek pracodawcy } \\
\text { do kobiet }\end{array}$} & Tak & 14,4 & 12,9 & 11,7 & 13,0 \\
\hline & $\mathrm{Nie}$ & 77,9 & 73,3 & 67,0 & 72,8 \\
\hline & Trudno powiedzieć & 7,7 & 13,8 & 21,4 & 14,2 \\
\hline \multirow{3}{*}{$\begin{array}{l}\text { Brak dostępu do niektórych } \\
\text { zawodów }\end{array}$} & Tak & 36,5 & 44,8 & 38,8 & 40,2 \\
\hline & Nie & 48,1 & 36,2 & 35,0 & 39,6 \\
\hline & Trudno powiedzieć & 15,4 & 19,0 & 26,2 & 20,1 \\
\hline \multirow{3}{*}{$\begin{array}{l}\text { Trudności w awansie na stanowiska } \\
\text { kierownicze }\end{array}$} & Tak & 24,0 & 31,0 & 21,4 & 25,7 \\
\hline & Nie & 61,5 & 51,7 & 51,5 & 54,8 \\
\hline & Trudno powiedzieć & 14,4 & 17,2 & 27,2 & 19,5 \\
\hline \multirow{3}{*}{$\begin{array}{l}\text { Większe obciążenie obowiązkami } \\
\text { zawodowymi }\end{array}$} & Tak & 16,3 & 20,7 & 24,3 & 20,4 \\
\hline & $\mathrm{Nie}$ & 67,3 & 55,2 & 52,4 & 58,2 \\
\hline & Trudno powiedzieć & 16,3 & 24,1 & 23,3 & 21,4 \\
\hline
\end{tabular}

Źródło: badania własne.

W opinii Polaków w funkcjonowaniu sfery zawodowej w Polsce zauważa się podobne sytuacje czy działania.

Dostrzegane symptomy braku równości płci na polu zawodowym to przede wszystkim: niższe w porównaniu z mężczyznami wynagrodzenie dla kobiet za tę samą pracę, brak możliwości awansu na wyższe stanowiska w firmie (te zarezerwowane są dla mężczyzn) oraz - podczas rekrutacji kryterium płci, a nie kompetencji. Kobiety częściej niż mężczyźni mówią w tym kontekście wprost 
Pobrane z czasopisma Annales I - Philosophy and Sociology http://philosophia.annales.umcs.pl Data: 26/04/2023 16:32:06

o dyskryminacji ze względu na funkcję macierzyńską - odrzucaniu aplikacji młodych kobiet z obawy przed ewentualną ciążą, obniżaniu wynagrodzenia matkom ze względu na brak dyspozycyjności czy wymuszaniu od pracownic deklaracji w sprawie niezachodzenia w ciążę w określonym czasie ${ }^{31}$.

Badania niestety potwierdzają wskazywane przez Polaków sytuacje dyskryminujące kobiety. Na rynku pracy widać dysproporcje między zatrudnianiem kobiet i mężczyzn. Pracodawcy obawiają się mniejszego zaangażowania kobiet w pracę, częstych zwolnień lekarskich i dni wolnych na opiekę nad dzieckiem. Kobiety są pytane o plany rodzicielskie, mimo że takie pytania są prawnie zabronione. A przecież, jak podkreślają autorzy badania - A. Woźniacka i J. Korona, kobieta po urodzeniu dziecka jest lojalnym pracownikiem wobec pracodawcy ze względu na mniejszą elastyczność wynikającą właśnie z jej zobowiązań rodzinnych ${ }^{32}$. Tym samym konieczna jest zmiana postaw pracodawców, wprowadzanie rozwiązań ułatwiających godzenie obowiązków zawodowych z rodzinnymi, a więc prowadzenie polityki przyjaznej pracującym matkom.

Jest to szczególnie ważne w przypadku kobiet powracających na rynek pracy po przerwie związanej z wychowywaniem dzieci. W badaniach J. Czarneckiej, K. Dzwonkowskiej-Goduli i P. Woszczyk matki wyartykułowały swoje obawy przed powrotem do pracy, które w większości dotyczą aspektów zawodowych. Niepokój kobiet wzbudzają przyszłe trudności w godzeniu obowiązków domowych z zawodowymi, potrzeba bycia dyspozycyjną w pracy, trudności wdrożenia w rytm pracy, a także brak uaktualnionej wiedzy i trudności z poradzeniem sobie z nowymi obowiązkami oraz obawy przed zmianą stanowiska pracy, warunków pracy czy nawet zwolnieniem z pracy ${ }^{33}$. Są to realne obawy kobiet, które warunkują ich funkcjonowanie w obu sferach - zawodowej i rodzinnej. Oczywiście w rodzinach, w których poziom partnerstwa i zaangażowanie mężczyzn w obowiązki domowo-opiekuńcze są większe, sytuacja pracujących kobiet jest „lżejsza”. Zmniejszeniu ulega podwójne obciążenie, którego doświadczają polskie kobiety. Pogodzenie wszystkich ról jest tym samym mniej konfliktowe.

\section{ZAKOŃCZENIE}

Aktywność zawodowa to znaczący element funkcjonowania współczesnych kobiet. Kobiety chcą podejmować pracę, chcą się w niej spełniać, osiągać cele i realizować swoje ambicje. Praca przynosi im satysfakcję, niezależność finansową,

31 Ibidem, s. 7-8.

32 A. Woźniakowska, J. Korona, op. cit., s. 46-47.

33 J. Czernecka, Wracam do pracy-podejmowanie przez kobiety aktywności zawodowej po przerwie związanej z opieka nad dzieckiem, [w:] Mama w pracy..., s. 127-128. 
wzmacnia poczucie wartości. Niestety, nadal postrzegane są stereotypowo jako pracownicy „kłopotliwi”, co rzutuje na ich samoocenę. Kobietom często brakuje wiary we własne możliwości i odwagi do podejmowania wyzwań. Tworzy się swoiste błędne koło - im bardziej kobiety nie podejmują starań o poprawę sytuacji na rynku pracy, tym bardziej mężczyźni utrzymują status quo. Skutkiem tego jest istnienie nierówności płci i różnych form dyskryminacji kobiet w sferze zawodowej. Rozwiązanie tego problemu społecznego wymaga odgórnych, instytucjonalno-prawnych działań. Wzmocnienie prawne sytuacji kobiet i legislacyjne ramy działania pracodawców mogą przyczynić się do niwelowania nierówności w traktowaniu kobiet i mężczyzn, choć kluczem zmian wydają się być przemiany w mentalności samych kobiet.

\section{BIBLIOGRAFIA}

Balcerzak-Paradowska B., Głogosz D., Hebda-Czaplicka I., Kołaczek B., Przekształcenia własnościowe a aktywność zawodowa kobiet. Zmiany i uwarunkowania, [w:] Praca kobiet w sektorze prywatnym. Szanse i bariery, red. B. Balcerzak-Paradowska, Warszawa 2003.

Czernecka J., Kobieta, matka, pracownik, [w:] Mama w pracy-społeczne uwarunkowania powrotu kobiet na rynek pracy po przerwie zwiazanej z wychowaniem dziecka, red. J. Czernecka, K. Dzwonkowska-Godula, P. Woszczyk, Łódź 2009.

Czernecka J., Wracam do pracy - podejmowanie przez kobiety aktywności zawodowej po przerwie zwiazanej z opieka nad dzieckiem, [w:] Mama w pracy-społeczne uwarunkowania powrotu kobiet na rynek pracy po przerwie zwiazanej z wychowaniem dziecka, red. J. Czernecka, K. Dzwonkowska-Godula, P. Woszczyk, Łódź 2009.

Domański H., Zadowolony niewolnik idzie do pracy, Warszawa 1999.

GUS, Kobiety i mężczyźni na rynku pracy, Warszawa 2016.

Jacukowicz Z., Zróżnicowanie płac w Polsce, w krajach Unii Europejskiej i w USA, Warszawa 2000.

Kalinowska-Nawrotek B., Dyskryminacja kobiet w sferze pracy i płacy, [w:] Przedsiębiorstwo i jego otoczenie. Przemiany i perspektywy, red. A. Manikowski, A. Psyk, t. 2, Warszawa 2007.

Kalinowska-Sufinowicz B., Polityka społeczno-gospodarcza państwa wobec pracy kobiet, Poznań 2013.

Kobieta pracujaca. Komunikat CBOS, Warszawa 2013.

Kwak A., Rodzina i jej przemiany, Warszawa 1994.

Kwak A., Pascall G., Kobiety na rynku pracy - bariery ptci, „Roczniki Socjologii Rodziny” 2005, nr 16.

Lisowska E., Równouprawnienie kobiet i mężczyzn w społeczeństwie, Warszawa 2010.

Matysiak A., Słoczyński T., Baranowska A., Kobiety i mężczyźni na rynku pracy, [w:] Zatrudnienie w Polsce 2008. Praca w cyklu życia, red. M. Bukowski, Warszawa 2010.

Ołdak M., Praca zawodowa w życiu polskich kobiet: jako wartość i doświadczenie, [w:] Wykształcenie $i$ kwalifikacje kobiet a ich sytuacja na rynku pracy, red. G. Firlit-Fesnak, Warszawa 2008.

Równouprawnienie ptci. Komunikat CBOS, Warszawa 2013.

Szklany sufit. Bariery i ograniczenia pracy kobiet, red. A. Titkow, Warszawa 2003.

Sztompka P., Socjologia. Analiza społeczeństwa, Kraków 2002.

Szuman A., Motywy pracy zawodowej matek pracujacych w fazach cyklu życia rodziny, Poznań 2001. 
Szyszka M., Kobiety między domem a praca. Oczekiwane wsparcie i instrumenty polityki rodzinnej na rzecz godzenia ról zawodowych z rodzinnymi, „Studia nad Rodziną” 2015, nr 36.

Titkow A., Duch-Krzystoszek D., Budrowska B., Nieodpłatna praca kobiet. Mity, realia, perspektywy, Warszawa 2010.

Woźniakowska A., Korona J., Raport z badania realizowanego w ramach projektu „,Mamy pracujące mamy”, Kielce 2011.

\section{SUMMARY}

The professional activity is an important part of the lives of modern women. The work brings them satisfaction, financial independence, strengthens self-esteem. However, they are stereotypically perceived as workers "troublesome", which affects their self-esteem. This article attempts to answer the questions: why women work professionally?, what factors are important?, what kind of benefits derived from professional women's activity? Finally, what women think about discrimination against women in the professional sphere? The analysis is based on the research conducted in 2016 among working women in Lublin.

Keywords: women; professional activity; discrimination against women in the professional sphere

\section{STRESZCZENIE}

Aktywność zawodowa to istotny element życia współczesnych kobiet. Praca przynosi im satysfakcję, niezależność finansową, wzmacnia poczucie wartości. Postrzegane są jednak stereotypowo jako pracownicy „kłopotliwi”, co rzutuje na ich samoocenę. Celem artykułu jest próba odpowiedzi na pytania: dlaczego kobiety pracują zawodowo?, czy tylko czynniki ekonomiczne mają znaczenie?, jakie korzyści czerpią kobiety z podejmowania aktywności zawodowej?, czy widzą siebie na stanowisku kierowniczym? Wreszcie, jaką mają opinię na temat dyskryminacji kobiet w sferze zawodowej i czy same spotkały się z jej przejawami? Analizy dokonano w oparciu o wyniki badań przeprowadzonych w 2016 r. wśród pracujących kobiet Lublina.

Słowa kluczowe: kobiety; aktywność zawodowa; dyskryminacja zawodowa kobiet 